határolására szolgáló modelleket, melyek elsōsorban a térrel, ezen belül a távolsággal és a tömeggel számolnak.

A VII.-VIII.-IX. fejezetek különböző módszereket sorakoztatnak fel, de mindegyikük hasonló területi problémák feltárására, kutatására alkalmas, mégpedig a területi gazdasági struktúra, gazdasági szerkezet $\mathrm{s}$ ezeknek a területi vetủleteinek kérdéseire keresik a választ. A VII. fejezetben RECHNITZER J. az input-output analizis modelljét mutatja be Baranya megyei esettanulmányaival alátámasztva. Röviden ismerteti a matematikai modellt, melyet az ágazati kapcsolatok mérlegének felhasználásával egy adott terület gazdasági szerkezetének belső és külsố kapcsolatainak feltárására használ fel. A szerzô a módszer elterjedésének legnagyobb gátját abban látja, hogy az alkalmazásához szükséges adatokat csak a gazdasági egységektôl lehetséges beszerezni. A VIII. fejezet a gazdasági függvények alkalmazási lehetôségeit tárgyalja a gazdaságföldrajzban. A szerzô, SIMON I., a CobbDouglas féle termelési függvényeket mutatja be, és a körzetek közötti gazdasági folyamatok feltárására és optimalizálására használja fel. Rendkívül újszerũ és a hazai területi vizsgálatokban még alig használt modelleket sorakoztat fel SIKOS T.T. a IX. fejezetben, amelyben a játékelmélet alkalmazhatóságát mutatja be a területi kutatásban. A modellek lehetöséget adnak egy termelési komplexum vagy terület optimalizálására. A szerzó is inkább távlati lehetőségeket lát ezekben a módszerekben, s a jövô kutatóinak ad ötleteket a játékelmélet modelljeinek felhasználására.

A könyv utolsó fejezete a gráfelmélet alkalmazhatóságát mutatja be egy már elvégzett vizsgálaton keresztül. SIMON I. az alföldi közúthálózat topológikus vizsgálatát végezte el, s betekintést ad a gráfelmélet gazdaságföldrajzban történó továb bi alkalmazhatóságáról.

A szerkesztő munkáját dicséri a kötet matematikai jelölésrendszerének összehangolása, mely elősegíti a különböző fejezetek kapcsolódási pontjainak gyors megtalálását és követhetôségét. Feltétlenül elismeréste méltó a fejezetekre bontott irodalomjegyzék, melyben mindenki az általa kiválasztott módszerhez megkaphatja a rendkívül részletes magyar és nemzetközi cikkek és szakkönyvek listáját, hogy ebböl témájának és érdeklődési körének megfelelóen, akár a matematikai módszerhez, akár annak felhasználási lehetôségeihez hozzájusson. Mi, a felhasználók köszönettel tartozunk SIKOS T. TAMĀSnak, aki alapos szerkesztői munkájának köszönhetően egy jól áttekinthetô, könnyen kezelhető, világosan fogalmazott módszertani könyvet bocsát rendelkezésünkre.

Szörényiné Kukorelli Irén

\title{
GÁSPÁR GABRIELLA: HAT FALU HAT SORSA
}

(MTA RKK Kutatási Eredményei, Pécs, 1986. 114 p.)

Településhálózatunkat a múltból örököltük, és a jelenben formáljuk a jövő számára. Az egyes történelmi korszakok, a gazdasági fejlôdés és a társadalmi átalakulás, a változó politikai rendszerek - ha eltérô mértékben is alakították, alakítják át a települések belsô képét, az ot télō emberek gondolkodását, életmódját, egymáshoz való viszonyát stb. A társadalomtudományok mưvelói évtizedek óta kutatják az átalakulás (a fejlódés és hanyatlás) általános vonásait, illetve helyi sajátosságait. A két világháború között kibontakozó szociográfiai irodalom elsổsorban a magyar paraszti társadalom kirivó ellentmondásait, a megoldásra váró szociális problémákat tárta fel megrázó erövel. Hasonló pozitív kezdeményezés volt a föld- és a néprajztudósoké is, akik a különbözó településtípusokat történeti fejlổdésükben vizsgálták. A felszabadulás utáni évtizedekben a közgazdasági és földrajzi szakirodalom elsốsorban a statisztikai adatok segitségével elemezte a termelőerôk területi átrendezódését, a vándorlási veszteség és nyereség településenkénti változásait. A hetvenes években az urbanizáció kibontakozása szükségszerúen együtt járt e folyamat ellentmon- 
dásainak megjelenésével. A városok egy részének túlnépesedése, a városi infrastruktúra hiánya, az ủj városi népesség, gyökértelenségéből" fakadó deviáns magatartási formák elterjedése jellemezte az egyik oldalt, míg a másik oldalon az ország egyes térségei és a falusi települések nagy része gyorsuló ütemben elvesztették népességük jelentốs hányadát. Igy fogalmazódott meg mind a társadalom, mind pedig a politikai vezetés igénye arra, hogy miként lehetne fokozni a kisvárosok és a falvak népességmegtartó erejét. Ezekhez a vizsgálatokhoz, valamint az elmaradott területek hatékony fejlesztési programjának kidolgozásához számos tudományág együttmúködésére volt szulkség (jog, gazdaság- és társadalomtörténet, földrajz, közgazdaságtan, szociológia stb.). A kutatási feladatok között szerepelt például a vidéki ipartelepités elókészítése, a szabad munkaerő felmérése, az életminôség vizsgálata, a racionálisabb közigazgatási módszerek alkalmazása stb. Az MTA RKK egyik kutatási programja is ezeket a feladatokat igyekszik összehangolni, megvalósítani. E kutatások egyik dokumentuma GASPAR GABRIELLA: Hat falu hat sorsa c. tanulmánya.

A szerző által vizsgált hat település - Bóly és öt társközsége: Borjád, Töttös, Kis- és Nagybudmér, valamint Pócsa - az 1977. évi területi átszervezés óta képez egy közigazgatási egységet. A települések Pécstól keletre mintegy 35-40 km-re, illetve Mohácstól nyugatra 20-25 km-távolságra, a Baranya-dombság és Villånyi-hegység által határolt, enyhén dombsági jellegú természeti környezetben találhatók. A Pécs-Villány-Mohács vasútvonal $k b$. 3-10 km-re közelíti meg az említett falvakat, amelynek együttes népességszáma hatezer kör üili. GÁSPÁR GABRIELLA kutatásai célját a következőképpen foglalta össze: „egy kis terület településein múködő helyi társadalmak jellegzetességeinek és hasonlóságainak vizsgálata a történeti folytonosság és a megszakítottság szellemében." A tanulmány szerkezete jól áttekinthetô, és végig érvényesül a szerző célkitúzése: „A társadalomszerkezet kialakulásának történeti elôzményeiroỏ" a XVIII. század elejétốl a felszabadulásig. A falvak újkori története jellegzetes Kárpát-medencei történelem. A török háborúk pusztításai nyomán néptelenné vált dunántúli területekre megindult a délszlávok (elsősorban rácok) bevándorlása, majd pedig a XVII1. század elsō felében a szervezett német telepítés. Kiegészitésként megjegyezhet- jük, hogy Bóly és környéke ahhoz a magyarországi németek által lakott területsávhoz kapcsolódott, amely Soprontól a Bakonyon át, Baranya és Tolna megyén keresztuil a Bácskáig, illetve a Bácskától egészen az Aldunáig húzódott. A XX. század elsó hét évtizedéig itt éló rácok (Borjád, Töttös, Pócsa, Nagybudmér) azoknak a szerb szórványoknak a részei voltak, amelyek szintén a XVIII. század folyamán jöttek létre a Duna mentén haladva egészen Szentendre vonaláig.

A magyarországi németek asszimilációja már a reformkorban megindult és a dualizmus évtizedeiben egyre erơteljesebbé vảlt. Amíg a városi német polgárság (föleg a dunántúli és alföldi) szinte teljesen elmagyarosodott, és a felemelkedő német anyanyelvü paraszti-kispolgári származású értelmiség a magyar középosztály részévé vált, addig a zártabb paraszti közösségek még a két világhảború között is megörizték német jellegüket. Joggal állapítja meg a szerzõ a negyvenes évek elejéról: „A helyi társadalmak struktúrájában elsôdleges elkülönülẻst jelentettek a nemzetiségi különbségek..."

A kẻt világháború közötti időszakban az egykor még igen jelentôs szerb etnikum lélekszáma és összlakosságon belüli aránya - a Jugoszláviába történô önkéntes átköltözés következményeként - minimálisra csökkent. (1880-ban még közel 20\%, 1941-re pedig már csak 1,5\%.) Ugyanakkor a német lakosság aránya növekvő tendenciát jelzett. (1880-ban még $73 \%$, 1941-ben pedig már $81 \%$.) A magyar etnikum aránya szintén emelkedő. (1880 ban kb. $5 \%$ körüli, 1941-ben kb. $17 \%$.) A magyarság gyarapodását két okkal magyarázhatjuk: egyrészt a környezố magyar falvakból, de még a trianoni határokon túli területekröl is magyarok költöztek be elsősorban Bólyra, másrészt pedig - s ez a folyamat is inkább Bólyt érintette - megindult egy arányaiban még nem számottevó asszimilációs folyamat (iparos és értelmiségi rétegek).

Az etnikai viszonyok elemzése mellett nem hanyagolta el GÁSPÁR GABRIELLA a gazdasági és társadalmi szerkezet átalakulásának bemutatását sem. Véleménye szerint: a vizsgált települések között már 1945 elött is létezett egyfajta ,hierarchia". Bóly nagyközség ,,modernnek" tekinthető társadalmi szerkezettel rendelkezett, ugyanis itt viszonylag magas volt $(50 \%$ felett) a nem mezógazdasági keresók aránya. A zárt német paraszti társadalom mellett jelen volt már egy vegyes magyar, illetve 
német eredetü iparos és értelmiségi réteg a maga eltérő szokásaival, értékrendjével, valamint egy zömmel magyarokból álló cselédréteg is élt itt. A további öt kisközségre a zárt német paraszti társadalom volt a jellemző, annak ellenére, hogy Borjád és Töttös bizonyos „modernizációs" jegyeket is felmutatott.

Milyen események és hogyan bontották meg az évtizedek, évszázadok alatt kialakult „modellt"? Érvényesülte a történeti folytonosság? Ezekre a kérdésekre kapunk választ a tanulmány második részében. A szerző a mélyinterjúkra alapozva elemzi a felszabadulás utáni népességmozgások eseményeit, okait: a németek kitelepítésének problémáját, a magyarcsehszlovák lakosságcserét és az úgynevezett belsố telepítést. A hazai történettudomány - szakítva a korábbi egyoldalúan negatív szemlélettel - a hetvenes évektől kezdve árnyaltabban vizsálja a magyarországi németek második világháborús szerepét. (TILKOVSZKY LORANT: Ez volt a Volksbund. Bp. 1978.)

Az egyes német települések helyi sajátosságait (kik és miért vagy éppen miért nem csatlakoztak a Volksbundhoz?; az 1941. évi népszámlálás idejének helyi politikai viszonyait, a II. világháború befejezését követő számonkérés településenkénti eltérô vonásait) még nem tárták fel kellóen. Igy a tanulmányban közölt beszélgetések a történészek számára is értékes adatokat jelenthetnek. Ezeket a kérdéseket boncolgatta GYARMATI LIVIA: Együttélés c. filmje is, amelynek országos visszhangja támadt.

Érdeklődéssel olvashatjuk a nagy mezôgazdasági kultúrával rendelkező mátyusföldi $\mathrm{Ne}$ gyed egykori lakosainak visszaemlékezéseit az 1947-48-ban lebonyolított magyar-csehszlovák lakosságcserérôl. Az 1954-től ismét Csehszlovákiához kerülő színmagyar falu négy és fél ezres lakosságából mintegy másfél ezer személyt telepítettek át a csehszlovák hatóságok $\mathrm{Ma}$ gyarországra, ahol részint a kitelepített németek helyére (Baranya, Tolna megye) és az önként kitelepülő szlovákok által visszahagyott ingatlanokba (Csanád megye) irányították őket.

A tanulmány harmadik fejezete: „A társadalmi csoportok mai elkülönülésének gyökerei a vizsgált településeken" címet kapta. A német eredetũ őslakosság, a felvidéki betelepültek: az úgynevezett cseszkó magyarok, a belföldi telepesek és a cigányok együttéléséból fakadó problémákat tárja fel. A hagyományok továbbélése, a régi és az új értékrend, az egyes településeken élốk közösségformáló erői mind szerepelnek a vizsgált szempontok között. A továbbiakban részletes képet kapunk a megváltozott gazdasági, társadalmi feltételekrốl: tsz-szervezés, az állami gazdaság, majd a mezőgazdasági kombinát megalakulása, új ipari munkahelyek létesítése. Végül az összegzésben a szerző a szakirodalom alapján elemzi az egyes falvak jelenlegi helyzetét és várható kilátásait. A bővülő társadalmú, funkciógazdaság Bóly jelenti az egyik pólust, mig a hanyatló társadalmú, funkciószegény Kisbudmér a másik végletet.

Bóly, amely ugyan elvesztette öslakosságának mintegy $40 \%$-át, meg tudta újítani önmagát: munkahelyet teremtett, kiépítette az infrastruktúrát, és a közigazgatási rendezés is e település segitségére volt. Az ideköltöző ,idegenek" megtalálták számításukat, s véglegesnek tekintették lakóhelyüket. A többi település a megújulásra különbözõ okok miatt kevésbé volt képes. (Természetesen ezeket is részletezi a tanulmány.) Az egész munkára az áttekinthetöség, a világos és olvasmányos stîus a jellemző. A történeti elemzést nagyon jól egészítik ki a táblázatok, statisztikai adatok és az előzőekben már értékelt mélyinterjúk. A tanulmány történeti részében előfordul ugyan egy-két pontatlanság, ez azonban nem csökkenti az igen színvonalas munka értékét. (A német anyanyelvü és nemzetiségü lakosság kitelepítésénél az 1941. évi népszámlálás bevallásait vették alapul, nem pedig az 1938. évit, vagy a magyar-csehszlovák lakosságcsere keretében Magyarországra települő felvidéki magyarokat az első hetekben - 1947 áprilismájus - a kitelepített németek helyére költöztették, késốbb - 1947 nyarától - párhuzamosan telepítettek a német, illetve a visszamaradt szlovák ingatlanokba.)

Hiányérzetünk csak egyetlen ponton támadt: a tanulmányt hasznos lett volna kiegészíteni egy térképvázlattal, amely a vizsgált településeket földrajzi környezetükben tünteti fel.

Hat falu alig hatezer lakosának sorsát követhettük nyomon, de az ő sorsuk, múltjuk, jelenük a 10,5 milliós magyarság múltja, jelene is. A tanulmányból számos ötletet meríthet a szociológiai, a történeti kutatás, hasznosan forgathatják a honismereti gyưjitőmunkát végzók, a szúkebb-tágabb környezetüket megismerni kivánó érdeklő́dốk is. Ezért célszerư lenne a tanulmány gondolatait szélesebb körben megismertetni.

Kugler József 